\section{INTRA-ORGANIZATIONAL TRUST AS A FACTOR THAT AFFECTS SATISFACTION WITH DOCTORAL STUDIES}

\author{
Dagmara Lewicka ${ }^{\mathrm{a}}$, Dawid Książek ${ }^{\mathrm{b}}$, Paulina Rożenek ${ }^{\mathrm{c}}$, \\ Anna Liisa Westman ${ }^{\mathrm{d}}$
}

\author{
a,b,c AGH University of Science and Technology, \\ Faculty of Management, Krakow, Poland \\ ${ }^{\mathrm{d}}$ University of Eastern, Finland \\ ae-mail: dagal@poczta.fm \\ be-mail: dawidksiazek9@gmail.com \\ ce-mail: paulina.rozenek.271@zarz.agh.edu.pl \\ de-mail: liisa.westman@gmail.com
}

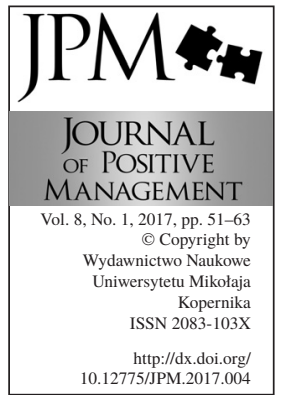

0.12775/JPM.2017.004

\begin{abstract}
The aim of the article is to examine intra-organizational trust as a factor impacting satisfaction with doctoral studies. The study on intra-organizational trust is related to three types of trust: vertical trust, horizontal trust and institutional trust. In turn, perceived satisfaction is linked to knowledge and competences gained at a university (academic satisfaction) and studying atmosphere (satisfaction with atmosphere). Furthermore, the following research questions were addressed in this paper: (1) Does personal experience from the past, current personal experience and the impact of surroundings affect particular types of trust? (2) Do particular types of trust and support provided by a university influence the willingness to take a risk? Therefore, in the underlying research the following factors that may be related to trust have been studied: university's support, willingness to take a risk, personal experience from the past, impact of surroundings. The sample consisted of $41 \mathrm{PhD}$ students (26 women and 16 men). The Jagiellonian University has been represented by 11 doctorate student, where as AGH University of Science and Technology surveyed $30 \mathrm{PhD}$ students. The results of the study allow to answer the research question by pointing out to particular types of intra-organizational trust at a university as factors that affect $\mathrm{PhD}$ students' satisfaction with doctoral studies. Study presents a positive correlation between intra-organizational trust and satisfaction at a university. Moreover, the impact of institutional trust on academic satisfaction and the influence of trust in lecturer and the impact of horizontal trust on satisfaction from atmosphere has been prove.
\end{abstract}

Keywords: intra-organizational trust, vertical trust, horizontal trust, institutional trust, satisfaction with studding

Paper type: Research paper 
INTRA-

ORGANIZATIONAL

TRUST AS A FACTOR

Dagmara Lewicka

Dawid Książek

Paulina Rożenek

Anna Liisa Westman

\section{Introduction}

The number of $\mathrm{PhD}$ students in Poland has increased significantly recently. According to the Supreme Chamber of Control, between 2007 and 2014 there was a major increase in the number of doctoral students, which amounted to $40 \%$ [1], and currently the number of doctoral students is 43200 [2]. It seems that the increase in the number of doctoral students is due to the fact that doctoral studies in Poland are less and less isolated from the labor market and they no longer have an autotelic function, but are significantly increasing the chances for professional development for postgraduates and doctoral students (Domaradzka and Walczak, 2013).

Due to the increasing interest in $\mathrm{PhD}$ studies and their role in the economy of a country, which increases its research potential and has a positive effect on innovation and growth (Smith et al., 2010), it seems to be justified to research the $\mathrm{PhD}$ students as internal stakeholders of the university. In addition to students, the following university stakeholders can be distinguished: students' parents, university administrative staff, academic staff, lecturers, and supervisors (Chapleo and Simms, 2010). In the light of the study of the social factors of doctoral students, what is of interest in the underlying publication, it is vital to emphasize the special role of the tutor and the lecturer in obtaining the $\mathrm{PhD}$ diploma. The model of relationship between a student and a supervisor created by Mainhard and others (2009) indicates the existence of eight dimensions of interpersonal behavior of the supervisor, that creates a proper relationship between him and the student: leadership, helpful / friendly, understanding, giving students freedom and responsibility, uncertainty, dissatisfied, admonishing and strict. In the literature the importance of communication between a supervisor and a student is emphasized (Andrew, 2012). The authors of this article want to complement the research in supervisor and student relationships by researching intra-organizational trust in a vertical context. In addition, they identify a gap in research on other types of trust that also concern $\mathrm{PhD}$ studies - trust to colleagues (horizontal) and institutions (institutional).

The purpose of this study is to verify the impact of intra-organizational trust at $\mathrm{PhD}$ studies on the satisfaction of doctoral students. Satisfaction is a concept that has been occurring in management science for several decades. It is defined as the positive feelings and attitudes of members of an organization to the work done, which results from a positive relationship regarding the responsibilities, coworkers and the working environment (Wexley and Youkl, 1984; Lewicka, 2010). In the light of doctoral studies, satisfaction may refer to a doctoral program, quality of lectures, cooperation with a supervisor or the support of the university in obtaining the $\mathrm{PhD}$ diploma. It may also be related to the need to perform specific duties by a PhD student such as, for example, participation in scientific/ research conferences or research publications. 
2. Intra-organizational trust at a University. The PhD students' perspective According to Grudzewski et al. (2009) trust can be defined as a voluntary dependence created by the belief, that entity $\mathrm{A}$ in the given situation becomes dependent on the entity $\mathrm{B}$ and feels safe, despite the fact that the negative consequences can occur. In turn, Tzafrir and Eitam-Meilik (2005) define trust as a willingness to invest personal resources in the relationship with another person or institution, which is the results of mutual positive interaction on the past. Simultaneously, it is worth noticing, that trust is a dynamic value -trust can be developed or may be lost (Lewicka and Krot, 2012).

The role of intra-organization trust for university has a strategic meaning. The reason for that is the fact that the atmosphere of trust impacts the educational function through:

- enabling information flow and knowledge management (McElroy, 2002),

- stimulating processes of knowledge sharing (Wang and RubenstainMontano, 2002),

- reinforcing knowledge-sharing in an organization (Hoe, 2002).

Mayer et al. (1995) distinguish three types of intra-organizational trust: vertical trust, horizontal trust and institutional (impersonal) trust. Vertical trust is connected to superior-subordinate relations, horizontal occurs in relations between members of an organization, and institutional trust is a trust between members and whole organization (Mayer et al., 1995). Institutional trust is a way in which a person perceives the way in which an organization is organized (procedures, technologies, management system, vision, competence, policy and justice) (Ellonen et al., 2008).

Vertical trust from $\mathrm{PhD}$ students' perspective may be considered in relation to $\mathrm{PhD}$ supervisor or lecturer. It is worth noticing that the role of supervisor recently became more complex and challenging (Pearson, 1999) and the relationship between a student and supervisor is a critical factor for earning a doctorate (Doloriet et al., 2012). According to Vilkinas (2002) nowadays academic supervisor needs to perform two roles: to be a knowledge expert and a manager. Supervisor should be perceived as an experienced researcher and a collaborator, that enables building a close trust relationship between a student and a supervisor (Buttery et al., 2005). Moreover, indicators of supervisor's effectiveness in four major categories can be found in the literature (Cullen et al., 1994). One of those categories describes supervisor as an organized person characterized by being approachable and friendly; being supportive and positive; being open-minded and prepared to acknowledge errors (Zhao, 2003). Those features of supervisor's attitudes seem to be a necessary condition in order to build trust in the studentsupervisor relations.

In this paper authors decided to distinguish between a supervisor and a lecturer. Lecturer has a similar role in the educational function at university, 
INTRAORGANIZATIONAL TRUST AS A FACTOR

Dagmara Lewicka Dawid Książek

Paulina Rożenek Anna Liisa Westman but individual interaction between students and lecturers occur less frequently than between students and supervisors. Student-lecturer cooperation involves knowledge transfer (Su and Wood, 2012) and does not consist in joint scientific research. Nevertheless, interactions between lecturers-students and supervisorsstudents are related to gaining knowledge at a university. Therefore, authors examine vertical trust in the context of both types of interactions.

Horizontal trust at the university is a relationship between students/ colleagues. This type of intra-organizational trust allows effective communication and has a positive influence on cooperation and knowledge gaining (Connel et al., 2003). In turn, institutional trust is a way in which a person perceives the way in which organization functions (procedures, technologies, management system, vision, competence, policy and justice) (Ellonen et al., 2008). In this context, members of an organization have trust in procedures, technology and objectives, what can stimulate the formation of affective commitment, while affective commitment can be related to a sense of pride in belonging to a well-managed and ethical organization (Lewicka and Krot, 2012). In connection with this, institutional trust at a university as a public institution can contribute to being proud of being its student, increase the level of the identification with a particular university and boost the satisfaction level of studding.

The literature review on the $\mathrm{PhD}$ trust and satisfaction allowed the authors to notice a research gap. There is no complex research focusing on the relationship between trust and satisfaction at $\mathrm{PhD}$ studies. An example of doctoral studies research is Sakurais's et al. (2012) paper in which authors focused on the factors affecting doctoral students' academic engagement, satisfaction with their studies, and dropping out. In turn, Arambewela and Hall (2009) focused on postgraduate students and their satisfaction, but not from the doctoral studies perspective. Therefore, the literature research indicates that there are no papers on relationship between trust and satisfaction at PhD studies - for this reason the underlying article has an original value for science.

\section{Methodology}

Students opinion surveys play a significant role in development of university's educational function. According to Rowley (2003) there are four main reasons for collecting students' feedback:

- to allow to comment on their courses and to used collected information in order to make improvements,

- to encourage students' reflection on their learning,

- to provide the universities indicators that will contribute to the reputation of a university in the marketplace,

- to allow students to expresse their level of satisfaction regarding their studies. 
Therefore, the purpose of this paper is to examine the impact of the intraorganizational trust on students' satisfaction by collecting the $\mathrm{PhD}$ student's opinions using the survey. Furthermore, the following research questions were addressed in this paper:

1. Does personal experience from the past, current personal experience and the impact of surroundings affect particular types of trust?

2. Do particular types of trust and support provided by a university influence the willingness to take a risk?

The intra-organizational trust is related to three types of trust: vertical trust, horizontal trust and institutional trust. In turn, perceived satisfaction is connected with the knowledge and competences gained at a university (academic satisfaction) and the atmosphere from studying (satisfaction with atmosphere).

The underlying research is a pilot study and a preliminary step to a large-scale research on this issue. The diagnostic survey method has been used as a method where the basic technique of collecting material was a questionnaire form. The questionnaire form consisted of 50 statements that have been answered by the respondents using a five-point Likert scale. The items on the questionnaire were developed by the authors on the basis of scales to study trust (Lewicka and Krot, 2015). They concern the following areas: trust, university's support, satisfaction with studying, willingness to take a risk, tendency to trust, trust or the lack thereof as a result of the experience gained at a university. The following variables were tested:

- institutional trust (3 statements), e.g. I know what is going on at my university/in my department, The authorities of my department keep their word;

- vertical trust in a lecturer (5 statements), e.g. I believe that my lecturer evaluates students fairly, I can give my feedback to the lecturer (regarding ideas, activities, lectures, etc.);

- vertical trust in a supervisor (8 statements), e.g. I can always ask my supervisor for help, My supervisor keeps her/his word;

- horizontal trust (9 statements), e.g. I can rely on fellow students, I can count on fellow students' help, I can count that fellow students will do what they promised;

- university's support (1 statement), e.g. I am thankful for the support I receive from my university;

- perceived satisfaction (7 statements), e.g. I would recommend this university to my friend, regarding the knowledge and competences gained at the university, e.g. I appreciate the competencies I gain at the university, regarding the atmosphere at the university, e.g. The atmosphere at the university is friendly;

- willingness to take a risk (3 statements), e.g. I willingly undertake risky ORGANIZATIONAL TRUST AS A FACTOR

Dagmara Lewicka Dawid Książek Paulina Rożenek Anna Liisa Westman 
INTRAORGANIZATIONAL TRUST AS A FACTOR

Dagmara Lewicka Dawid Książek

Paulina Rożenek Anna Liisa Westman activities, I am afraid of new tasks, I am eager to perform tasks out of my comfort zone;

- personal experience from the past (2 statements), e.g. I have experienced situations where fellow students took advantage of my work, In the past there were situations when my fellow students have used my work without my consent;

- current positive personal experience (2 statements) regarding the studying at the university, e.g. Whilst preparing a joint project we always share responsibilities equally, I always try not to disappoint my fellow students;

- impact of surroundings (3 statements) regarding a general perception of surroundings as friendly and trustworthy, e.g. I believe that my university is for the benefits of its students, I believe I can trust most of the people at my university.

The population for this research consists of $\mathrm{PhD}$ students of the fourth year of doctoral studies at the Jagiellonian University and AGH University of Science and Technology. The survey questionnaire was sent to deliberately selected $\mathrm{PhD}$ students (45 from the AGH University of Science and Technology; Faculty of Management and 30 from the Jagiellonian University; Faculty of Management), for whom the authors were convinced of the reliability of completing the questionnaire survey. Out of 75 respondents, 41 completed questionnaires (55\%) were returned. The sample consisted of 26 women and 16 men. The authors decided to choose for data collection the Jagiellonian University because it is on the current list of the Academic Ranking of World Universities [3]. Moreover, two authors of this paper are the PhD student at the AGH University of Science and Technology. Due to this reasons those two universities were chosen for pilot research. The Jagiellonian University has been represented by 11 doctorate student, where AGH University of Science and Technology surveyed $30 \mathrm{PhD}$ students. The average age of the respondents was 28.5 years old. The questionnaires have been distributed via e-mails and the respondents have been informed about the purpose of the study. The respondents of the questionnaire were ensured the anonymity.

\section{Research results}

The multiple progressive regression method was used in the research in order to obtain answers to the research questions, such as identifying factors affecting the actual level of satisfaction of respondents and identifying factors that impact the level of satisfaction from studying and willingness to take a risk, or to go out of the comfort zone. It was assumed that the so-called actual level of trust will be impacted by: personal experience from the past, current experience and influence of surroundings. Below are presented the models including the impact of the considered factors on the various types of trust: institutional, vertical and horizontal (Table 1 and 2). 
The statistically significant independent variable for institutional trust and trust in supervisor is the impact of surroundings. The econometric models, where the independent variable is: $\mathrm{x}_{1}$ - impact of surroundings, and the dependent variable is: $y$ - institutional trust, and the other model including vertical trust in supervisor, have been presented below. The models are:

$$
\begin{gathered}
Y-0.5 X_{1}+1.5 \quad \text { (for institutional trust) } \\
Y-0.4 X_{1}+2.8 \quad \text { (for vertical trust in supervisor) }
\end{gathered}
$$

\begin{tabular}{lcccc}
\hline $\mathbf{N}=\mathbf{4 1}$ & $\mathbf{B}$ & Std. error of $\mathbf{b}$ & $\mathbf{t}(\mathbf{3 9})$ & $\mathbf{p}$ \\
\hline \multicolumn{5}{c}{ Dependent variable institutional trust } \\
\hline Absolute term & 1.51 & 0.51 & 2.95 & 0.005309 \\
\hline Impact of surroundings & 0.5 & 0.15 & 3.38 & 0.001623 \\
\hline \multicolumn{5}{c}{ Dependent variable vertical trust in supervisor } \\
\hline Impact of surroundings & 2.8 & 0.51 & 5.48 & 0.000003 \\
\hline
\end{tabular}

The value $\mathrm{R}^{2}=0.21$ in case of the impact of surroundings on the institutional trust indicates that this model explains $21 \%$ of the variability of the dependent variable. In turn, the value $\mathrm{R}^{2}=0.13$ in case of the impact of surroundings on the vertical trust in supervisor indicates that the model explains $13 \%$ of the variability of the dependent variable.

Current personal experience and experience from the past turned out to be relevant when it comes to horizontal trust. Below, the econometric models in which independent variables are: $\mathrm{x}_{1}$ - current personal experience, $\mathrm{x}_{2}-$ personal experience from the past; $\mathrm{y}$ - horizontal trust, and the other model including vertical trust in supervisor, have been presented below. The models are:

$$
Y-0.38 X_{1}+0.16 X_{3}+1.5
$$

\begin{tabular}{lcccc}
\hline $\mathbf{N}=\mathbf{4 1}$ & $\mathbf{b}$ & Std. error of $\mathbf{b}$ & $\mathbf{t}(\mathbf{3 8})$ & $\mathbf{p}$ \\
\hline Absolute term & 2.87 & 0.61 & 4.68 & 0.000035 \\
\hline Current personal experience & 0.38 & 0.13 & 2.76 & 0.008731 \\
\hline Personal experience from the past (negative) & -0.16 & 0.07 & -2.15 & 0.037567 \\
\hline
\end{tabular}

The value $\mathrm{R}^{2}=0.25$ in case of the impact of surroundings on the institutional trust indicates that this model explains $25 \%$ of the variability of the dependent variable.
INTRAORGANIZATIONAL TRUST AS A FACTOR

Dagmara Lewicka Dawid Książek Paulina Rożenek Anna Liisa Westman

Table 1. Factors influencing institutional trust and trust in supervisor

Source: own elaboration.

Table 2. Factors influencing horizontal trust Source: own elaboration. 
INTRAORGANIZATIONAL TRUST AS A FACTOR

Dagmara Lewicka Dawid Książek Paulina Rożenek Anna Liisa Westman

Table 3.

Factors influencing satisfaction from studying (synthetic variable)

Source: oawn elaboration.

Table 4.

Factors influencing academic satisfaction

Source: own elaboration.
In the next step of the research, the impact of particular types of trust and the university's support on the satisfaction from studying and willingness to take a risk has been examined. The models for a synthetic variable describing satisfaction and separately for two aspects deciding about the satisfaction, have been prepared (Table 3, 4, and 5).

Institutional trust, horizontal trust and vertical trust in supervisor turned out to be relevant when it comes to a general satisfaction. Below, an econometric model in which independent variables are: $\mathrm{x}_{1}-$ institutional trust, $\mathrm{x}_{2}$ - horizontal trust; $\mathrm{x}_{3}$ - vertical trust: $\mathrm{y}-$ satisfaction from studying, has been presented below. The model is:

$$
\mathrm{Y}-0.27 X_{1}+0.29 X_{2}+0.23 X_{23}+1.9
$$

\begin{tabular}{llclc}
\hline $\mathbf{N}=\mathbf{4 1}$ & $\mathbf{B}$ & Std. error $\mathbf{~ f ~} \mathbf{b}$ & $\mathbf{t}(\mathbf{2 7})$ & $\mathbf{p}$ \\
\hline Absolute term & 0.95 & 0.53 & 1.8 & 0.078722 \\
\hline Institutional trust & 0.27 & 0.11 & 2.44 & 0.019268 \\
\hline Horizontal trust & 0.29 & 0.11 & 2.52 & 0.015988 \\
\hline Vertical trust in supervisor & 0.23 & 0.11 & 2.05 & 0.046508 \\
\hline
\end{tabular}

The value $\mathrm{R}^{2}=0.5$ in case of the impact of institutional trust, horizontal trust and vertical trust in supervisor on the satisfaction from studying indicates that this model explains $50 \%$ of the variability of the dependent variable.

Additionally, two regression models were developed in order to obtain precise information regarding the factors affecting the particular aspects of satisfaction, such as: satisfaction with the knowledge and competences gained at a university and the atmosphere at a university.

\begin{tabular}{lcccc}
\hline $\mathbf{N}=\mathbf{4 1}$ & $\mathbf{B}$ & Std. error $\mathbf{~ f} \mathbf{b}$ & $\mathbf{t}(\mathbf{3 8})$ & $\mathbf{p}$ \\
\hline Absolute term & 1.83 & 0.51 & 3.53 & 0.001080 \\
\hline Institutional trust & 0.62 & 0.15 & 3.95 & 0.000316 \\
\hline
\end{tabular}

The value $R^{2}=0.27$ in case of the impact of institutional trust on academic satisfaction indicates that this model explains $27 \%$ of the variability of the dependent variable.

The value $\mathrm{R}^{2}=0.4$ in case of the impact of trust in lecturer and horizontal trust on the academic satisfaction indicates that this model explains $40 \%$ of the variability of the dependent variable.

In the last step of the research, the authors developed a model that would identify the factors impacting the willingness to take a risk. This model has shown a significant impact of trust in lecturer on willingness to take a risk. The model is: 


\begin{tabular}{lcccc}
\hline $\mathbf{N}=\mathbf{4 1}$ & $\mathbf{b}$ & Std. error of $\mathbf{b}$ & $\mathbf{t}(\mathbf{3 8})$ & $\mathbf{p}$ \\
\hline Absolute term & 0.62 & 0.65 & 0.96 & 0.338960 \\
\hline Trust in lecturer & 0.53 & 0.16 & 3.31 & 0.002048 \\
\hline Horizontal trust & 0.37 & 0.17 & 2.18 & 0.034877 \\
\hline
\end{tabular}

$$
Y-0.33 X_{1}+1.71
$$

The value $R^{2}=0.08$ in this case indicates that this model explains only $8 \%$ of the variability of the dependent variable.

\section{Conclusions}

The results of this study allow to verify the research aim by indicating the particular types of intra-organizational trust at a university as factors that affect PhD students' satisfaction with doctoral studies. It is worth noticing that institutional trust and horizontal trust in lecturer seem to be important, whilst horizontal trust in a supervisor not so much. Correspondingly, the research focused on the same relationship between trust and satisfaction but regarding the employees and companies also confirm the positive impact of organizational trust on job satisfaction (Perry and Mankin, 2007; Guinot et al., 2014). Thus, results of this studies endorse authors expectations regarding the scientific value of researching social factors (organizational trust and satisfaction) in a new context which is a university.

Moreover, the following conclusions regarding the research questions can be stated:

1. It is not surprising that the satisfaction from the atmosphere at a university is influenced by such factors as horizontal trust in colleagues and trust in lecturers. It seems that these interpersonal relationships have the greatest impact on the atmosphere as they stimulate the intensity of contacts, cooperation, information flow and knowledge exchange (Moye et al., 2005; McElroy, 2002; De Jong and Woolthuis, 2008).

2. The surprising fact is that the institutional trust is a factor that explains the academic satisfaction of the questioned students. Although $\mathrm{PhD}$ students recruit from high-ranking universities in Poland it would seem that the contact with a supervisor should be a significant factor to satisfaction strictly bound with academic research. This factor impacts only an overall satisfaction from studying.

3. The results indicate that the level of institutional and vertical trust is affected by the personal tendency to trust that is expressed in particular positive beliefs regarding the fact that it is worth trusting people 
INTRAORGANIZATIONAL TRUST AS A FACTOR

Dagmara Lewicka Dawid Książek

Paulina Rożenek Anna Liisa Westman associated with a university and that the university considers interest of the individuals and sets it as its priority.

4. On the other hand, the level of horizontal trust is impacted by current positive personal experience related to effective cooperation, fair division of tasks in joint projects as well as negative experience from the past, when the respondent was taken advantage of by his/her colleagues and the work was not fairly distributed.

5. The relatively low level of $\mathrm{R}^{2}$ in the obtained models indicate that, in addition to the variables that were taken into account, there are other that affect the researched variables. For example, perceived satisfaction is largely determined by personality factors, as well as by willingness to take a risk (Mayer et al., 1995).

6. Taking into account the above mentioned considerations, it can be noticed need to improve the level of vertical trust in a supervisor, especially relationship between student and supervisor is a critical factor for earning a doctorate (Doloriet et al., 2012).

The presented study is a pilot research and it requires further research. That is why presented research approach is not free from limitations, including the limitations of the test method, sample selection and a limited set of variables. Results of questionnaire surveys, i.e. respondents' opinions are declarative, which is undoubtedly a limitation of the survey. In a future research should be conducted on a random sample, taking into account the unit of analysis which is the type of University. As a more correct solution, the authors would definitely suggest supplementing the quantitative research with qualitative research.

In order to create a better adjusted model that will explain the determinants, it is necessary to consider the new variables in the model, such as sociodemographic variables. In the course of further research, the emphasis should be put on the confirmation of the enriched model based on the structural equation modeling (SEM). The valuable opportunities for research direction can include the identification of the main factors impacting the level of trust and satisfaction using a larger sample for data collection. Also, it is worth testing a relationship between other social factors which are presented in companies area research, such as knowledge sharing (Kuo, 2013) or citizenship behavior (Organ et al., 2006).

\section{Notes}

[1] https://www.nik.gov.pl/plik/id,9897,vp,12191.pdf, p. 9.

[2] Higher Education Institution and their Finances in 2015, Central Statistical Office, Warsaw 2016.

[3] http://www.shanghairanking.com/ARWU2017.html 
Andrew, M. (2012), "Supervising doctorates at a distance: three trans-Tasman stories", Quality Assurance in Education, Vol. 20 No. 1, pp. 42-53.

Arambewela, R., Hall, J. (2009), "An empirical model of international student satisfaction”, Asia Pacific Journal of Marketing and Logistics, Vol. 21 No. 4, pp. 555-569. DOI: 10.1108/13555850910997599

Blau, P. M. (1964), Exchange and Power in social life, Wiley, New York.

Buttery, E. A., Richter, E. M., Filho, W. L. (2005), "An overview of the elements that influence efficiency in postgraduate supervisory practice arrangements", International Journal of Educational Management, Vol. 19 No. 1, pp. 7-26.

Chapleo, Ch., Simms, Ch. (2010), "Stakeholder analysis in higher education. A case study of the University of Portsmouth", Perspectives: Policy and Practice in Higher Education, Vol. 14 No. 1, pp. 12-20.

Connell, J., Ferres, N., Travaglione, A. (2003), "Engendering Trust in Manager-Subordinate Relationships: Predictors and Outcomes", Personnel Review, Vol. 32 No. 5, pp. 569-590.

Cropanzano, R., Mitchell, M. S. (2005), "Social exchange theory: an interdisciplinary review", Journal of Management, Vol. 31 No. 6, pp. 874-900. DOI: 10.1177 /0149206305279602

Cullen, D. J., Pearson, M., Saha, L., Spear, R. H. (1994), Establishing Effective PhD Supervision, Higher Education Division, Evaluation and Investigations Program, Australian Government Publishing Service, Canberra.

De Jong, G., Woolthuis, K. R. (2008), “The Institutional Arrangements of Innovation: Antecedents and Performance Effects of Trust in High-Tech Alliances", Industry and Innovation, Vol. 15 No. 1, pp. 45-67.

Doloriert, C., Sambrook, S., Stewart, J. (2012), "Power and emotion in doctoral supervision: implications for HRD”, European Journal of Training and Development, Vol. 36 No. 7, pp. 732-750. DOI: 10.1108/03090591211255566

Domaradzka, A., Walczak, D. (2013), "Wartość autoteliczna czy intrumentalna? Rola studiów doktoranckich w opinii kierowników studiów i doktorantów", Nauka i Szkolnictwo Wyższe, No. 2/42, pp. 73-95.

Freeman, R. E. (2010), Strategic Management. A stakeholder approach, Cambridge University Press, Cambridge.

Grudzewski, W. M., Hejduk, I. K., Sankowska, A., Wańtuchowicz, M. (2009), Zarządzanie zaufaniem w przedsiębiorstwie, Wydawnictwo Oficyna, Kraków.

Guinot, J., Chiva, R., Roco-Puig, V. (2014), "Interpersonal trust, stress and satisfaction at work: an empirical study", Personnel Review, Vol. 43 No. 1, pp. 96-115. DOI: 10.1108/PR-02-2012-0043

Hoe, L. S. (2002), "Is interpersonal trust a Necessary Condition for Organizational Learning", Journal of Organisational Transformation and Social Change, Vol. 4 No. 2, pp.149-156.

Krot, K., Lewicka, D. (2012), “The importance of trust in manager -employee relationship", International Journal of Electronic Business Management, Vol. 10 No. 3, pp. 224-333.
ORGANIZATIONAL TRUST AS A FACTOR

Dagmara Lewicka

Dawid Książek

Paulina Rożenek

Anna Liisa Westman 
INTRAORGANIZATIONAL TRUST AS A FACTOR

Dagmara Lewicka Dawid Książek

Paulina Rożenek Anna Liisa Westman
Kuklińkski, A. (2003), "Gospodarka oparta na wiedzy-społeczeństwo wiedzy-trajektoria regionalna", Nauka i Szkolnictwo Wyższe, No. 2/22.

Kuo, T. (2013), "How expected benefit and trust influence knowledge sharing", Industrial Management \& Data Systems, Vol. 113 No. 4, pp. 506-522. DOI: 10.1108 /02635571311322766

Kwaśniewska, K. (2015), “Funkcje Szkoły Wyższej w społeczności lokalnej”, Studia z zakresu nauk prawnoustrojowych Miscellanea, No. 5, pp. 267-274.

Lewicka, D., Krot, K. (2015), “The model of HRM-trust-commitment relationship", Industrial Management and Data Systems, Vol. 115 No. 8 pp. 1457-1480. DOI: 10.1108/IMDS-12-2014-0388

Mainhard, T., Rijst, R., Tartwijk, J., Wubbels, T. (2009), “A model for the supervisordoctoral student relationship", Higher Education, Vol. 58 No. 3, pp 359-373. DOI: 10.1007/s10734-009-9199-8

Mayer, R. C., Davis, J. H., Schoorman, D. (1995), “An integrative model of organizational trust", Acadamy of Management Review, Vol. 20 No. 3, pp. 709-734.

McElroy, M. W. (2002), "Social Innovation Capital”, Journal of Intellectual Capital, Vol. 3 No. 1, pp. 30-39.

Moye, M. J., Henkin, A. B., Egley, R. J. (2005), “Teacher-principal relationships: Exploring linkages between empowerment and interpersonal trust", Journal of Educational Administration, Vol. 43 No. 3, pp. 260-277.

Organ, D. W., Podsakoff, P. M., McKenzie, S. B. (2006), Organizational citizenship behavior: its nature, antecedents, and consequences, Sage, Thousand Oaks.

Pearson, M. (1999), “The changing environment for doctoral education in Australia: implication for quality management, improvement and innovation", Higher Education Research and Development, Vol. 18 No. 3, pp. 269-287.

Perry, R. W., Mankin, L. D. (2010), “Organizational Trust, Trust in the Chief Executives and Work Satisfaction”, Public Personel Management, Vol. 36 No. 2, pp. 165-179.

Rowley, J. (2003), "Designing student feedback questionnaires", Quality Assurance in Education, Vol. 11 No. 3, pp. 142-149. DOI: 10.1108/09684880310488454

Sakurai, Y., Pyhältö, K., Lindblom-Ylänne, S. (2012), "Factors affecting international doctoral students' academic engagement, satisfaction with their studies, and dropping out", International Journal for Researcher Development, Vol. 3 No. 2, pp. 99-117.

Schwabsky, N. (2014), "Teachers' individual citizenship behavior (ICB): the role of optimism and trust", Journal of Educational Administration, Vol. 52 No. 1, pp. 37-57. DOI: 10.1108/JEA-08-2012-0092

Smith, A., Bradshaw, T., Burnett, K., Docherty, D., Purcell, W., Worthington, S. (2010), "One step beyond: making the most of postgraduate education", report for UK Department for Business Innovation and Skills, London, available at: www.bis.gov. uk/assets/biscore/corporate/docs/p/10-704-one-step-beyond-postgraduate-education. pdf (accessed 11 May 2016).

Su, F., Wood, M. (2012), "What makes a good university lecturer? Students' perceptions of teaching excellence", Journal of Applied Research in Higher Education, Vol. 4 No. 2, pp.142-155.

Takleab, A. G., Takeuchi, R., Taylor, M. S. (2005), "Extending the Chain of Relationships 
among Organizational Justice. Social Exchange and Employee Reactions: The role of contract violations", Academy of Management Journal, Vol. 48, pp. 146-157.

Tarvid, A. (2017) "Attracting doctoral students: case of Baltic universities", International Journal of Educational Management, Vol. 31 No. 7, pp. 1017-1041. DOI: $10.1108 / 17581181211273110$

Tzafrir, S. S., Eitam-Meilik, M. (2005), “The impact of Dowsizing on Trust and Employee Practices in High Tech Firms: A longitudinal analysis", Journal of High Technology Management Research, Vol. 16 No. 2, pp. 193-207. DOI: 10.1016/j.hitech.2005.10.008

Vilkinas, T. (2002), "The PhD process: the supervisor as manager", Education + Training, Vol. 44 No. 3, pp. 129-137. DOI: 10.1108/00400910210424337

Wang, R., Rubenstain-Montano, B. (2002), “The Value of trust in knowledge sharing”, in: Proceedings of the 2002 IRMA International Conference, PA: Idea Group Publishing, Hershey, pp. 116-130.

Wnuk-Lipińska, E. (1996), "Uniwersytet dzisiaj - idea, cele i zadania”, Nauka i Szkolnictwo Wyższe, No. 2/8, pp. 5-28.

Zhao, F. (2001 ), "Postgraduate Research Supervision: A Process of Knowledge Management", a vailable at: http://www.providersedge.com/docs/km_articles/Postgrad_Research_Supervision_-_A_Process_of_KM.pdf (accessed 25 June 2017).
INTRAORGANIZATIONAL TRUST AS A FACTOR

Dagmara Lewicka Dawid Książek Paulina Rożenek Anna Liisa Westman 